\title{
Variable sequence of events during the past seven terminations in two deep-sea cores from the Southern Ocean
}

\author{
Aya Schneider Mor ${ }^{\text {a,* }}$, Ruth Yam ${ }^{\text {a }}$, Cristina Bianchi ${ }^{\text {b }}$, Martina Kunz-Pirrung ${ }^{\text {b }}$, \\ Rainer Gersonde ${ }^{\mathrm{b}}$, Aldo Shemesh ${ }^{\mathrm{a}}$ \\ a Weizmann Institute of Science, P.O. Box 26, 76100 Rehovot, Israel \\ ${ }^{\mathrm{b}}$ Alfred Wegener Institute for Polar and Marine Research, P.O. Box 120161 Columbusstrasse, 27515 Bremerhaven, Germany
}

\section{A R T I C L E I N F O}

Article history:

Received 11 March 2011

Available online 19 December 2011

\section{Keywords:}

Termination

Sequence of events

Southern Ocean

Diatom

Carbon and nitrogen isotopes

Glacial-interglacial

\begin{abstract}
A B S T R A C T
The relationships among internally consistent records of summer sea-surface temperature (SSST), winter sea ice (WSI), and diatomaceous stable isotopes were studied across seven terminations over the last $660 \mathrm{ka}$ in sedimentary cores from ODP sites 1093 and 1094. The sequence of events at both sites indicates that SSST and WSI changes led the carbon and nitrogen isotopic changes in three Terminations (TI, TII and TVI) and followed them in the other four Terminations (TIII, TIV, TV and TVII). In both TIII and TIV, the leads and lags between the proxies were related to weak glacial mode, while in TV and TVII they were due to the influence of the mid-Pleistocene transition. We show that the sequence of events is not unique and does not follow the same pattern across terminations, implying that the processes that initiated climate change in the Southern Ocean has varied through time.
\end{abstract}

(C) 2011 University of Washington. Published by Elsevier Inc. All rights reserved.

\section{Introduction}

Terminations are rapid transitions between glacial and interglacial climate states and are well-documented in marine sedimentary records, in ice cores, and by other continental climate indicators such as speleothems and loess sequences (Broecker, 1984; Petit et al., 1999; Sun et al., 2006; Vaks et al., 2006; Markovic et al., 2007; Wang et al., 2008). Generally, terminations differ in their duration and in the magnitude of the measured proxy over the past $800 \mathrm{ka}$ (Lisiecki and Raymo, 2005; Jouzel et al., 2007). The processes that govern these rapid transitions and control the magnitude of each termination are still controversial. Historically, the terminations and the observed variability in their magnitude and duration have been attributed to changes in the geometry of Earth's orbit ("Milankovitch cycles"). However, it was soon recognized that the associated changes in radiation were not large enough to trigger the glacialinterglacial transitions (Hays et al., 1976; Imbrie et al., 1992; Imbrie et al., 1993), and a complex suite of processes and feedback mechanisms that accompanied the radiation variation were invoked to explain them. These included changes in atmospheric $\mathrm{CO}_{2}$ concentration, thermohaline circulation (THC), ocean productivity, and the buildup and retreat of major ice sheets and sea ice (e.g. Sarmiento and Toggweiler, 1984; Broecker and Denton, 1989; Archer and Johnson, 2000; Stephens and Keeling, 2000). In addition,

\footnotetext{
* Corresponding author at: Stanford University, 367 Panama St., Stanford, CA 94305, USA.

E-mail address: ayaschm@stanford.edu (A. Schneider Mor).
}

a mechanism was proposed that involves Southern Oceanic overturning and carbonate accumulation in the deep ocean (Toggweiler, 2008).

Only terminations TI and TII were isotopically studied in detail in the Southern Ocean and Antarctica using records from sediment cores (Shemesh et al., 2002; Bianchi and Gersonde, 2004) and ice cores (Broecker and Henderson, 1998; EPICA community members, 2004; Jouzel et al., 2007). High-resolution records across Termination I in the Atlantic sector of the Southern Ocean show that, during the transition from the last glacial maximum to the Holocene, between 20 and $10 \mathrm{ka}$, sea-ice extent, SSST, and productivity changed to their interglacial values $2 \mathrm{ka}$ before atmospheric $\mathrm{pCO}_{2}$ increased to its high interglacial value (Shemesh et al., 2002).

Another study, which was based on a diatom transfer function and foraminifera isotopes, compared sediment cores from the Atlantic sector with ice cores and showed that the rise in sea-surface temperature occurred in parallel with an increase in atmospheric $\mathrm{CO}_{2}$ (Bianchi and Gersonde, 2004). On the other hand, the multi-proxy analysis of Vostok ice cores revealed that at Terminations I and II, the $\delta \mathrm{D}$ and $\mathrm{CO}_{2}$ concentrations 'responded' before $\delta^{18} \mathrm{O}_{\mathrm{atm}}$, meaning that $\mathrm{CO}_{2}$ concentration in the atmosphere rose before the ice sheets began to melt in the Northern Hemisphere (Broecker and Henderson, 1998). Thus, these studies assess the role of $\mathrm{CO}_{2}$ during the last Termination differently. We note, however, that only sediments from Termination I can be directly dated. Leads and lags between ice-core $\mathrm{CO}_{2}$ and marine sediments during older terminations, and the conclusions drawn from them, strongly depend on the age model assigned for the core. 
Climate models provide a useful tool for reconstructing possible glacial-interglacial climatic processes, especially in the Southern Ocean where limited sedimentary records are available. Several models presented competing mechanisms to control and describe the glacial-interglacial transitions in the Sothern Ocean. They included changes in thermohaline circulation (Shin et al., 2003; Paillard and Parrenin, 2004), productivity in surface waters of the Southern Ocean (Anderson et al., 2002; Brzezinski et al., 2002; Sarmiento et al., 2004), changes in the Antarctic ice sheet extend (Micolajewicz, 1998; Knorr and Lohmann, 2003; Knorr and Lohmann, 2007), insolation (e.g.: Imbrie and Imbrie, 1980; Shackleton, 1987; Broecker and Peng, 1989; Ruddiman et al., 1989; Imbrie et al., 1993), and ice loading (Gildor and Tziperman, 2000; Gildor and Tziperman, 2001). These models established that the Southern Ocean have an essential role in global glacial-interglacial changes. Therefore, studies of long records from the Southern Ocean are important for constraining the role which the different mechanisms play.

We studied two sediment records recovered at ODP Sites 1093 and 1094 in order to establish the relationships among SSST, WSI, and the chemical and biological parameters of Southern Ocean surface water (Fig. 1). We present high-resolution records of the $\delta^{13} \mathrm{C}$ and $\delta^{15} \mathrm{~N}$ of diatom bound organic matter $\left(\delta^{13} \mathrm{C}_{\mathrm{D}}\right.$ and $\delta^{15} \mathrm{~N}_{\mathrm{D}}$, respectively), which provide information on productivity and nutrient utilization in the Antarctic Zone, combined with SSST and WSI records throughout the past $660 \mathrm{ka}$. This is the first time these four proxies are compared to study the sequence of event at the Southern Ocean over the past seven terminations. The sequence of events at each termination in both sites is determined and classified according to the lags and leads between the parameters across the transition from full glacial to full interglacial conditions in an attempt to identify what drove climate change in each instance. The internal consistency of our data set allows us to test the relative lags and leads among the oceanographic parameters independently of the age model assigned to the records.

\section{Methods}

Sediment cores ODP site 1093 and ODP site 1094 were drilled during ODP Leg 177 in the Atlantic sector of the Southern Ocean, south of the Polar Front (Schneider-Mor et al., 2008; Fig. 1). Site 1093 (4958.58'S, $5^{\circ} 51.92^{\prime} \mathrm{E}$ ) is located north of Shona Ridge and near the modern day Polar Front in a water depth of $3624 \mathrm{~m}$. Site $1094\left(53^{\circ} 10.8^{\prime} \mathrm{S}, 5^{\circ} 7.8^{\prime} \mathrm{E}\right)$, is located in a sedimentary basin north of Bouvet Island, and north of the average extent of modern winter sea ice, in a water depth of $2807 \mathrm{~m}$. The age models of both cores were established according to the Epica Dome C (EDC) ice-core records (EPICA community members, 2004) and EDC2 is the age model applied to the section between 400 and 640 ka (Parrenin et al., 2004). However, revised age model EDC3 shows that MIS 15 as presented in EDC2 is too long (Parrenin et al., 2007). The construction of the age model is based on the graphic correlation of the $\delta \mathrm{D}$ and dust records from Epica Dome $\mathrm{C}$ with the records of the transfer function derived SSST, $N$. pachyderm $\delta^{18} \mathrm{O}$ (Hodell et al., 2003), and magnetic susceptibility measurements (Gersonde et al., 1999) obtained at ODP sites 1093 and 1094.

The cores were sampled in 5 to $15 \mathrm{~cm}$ intervals for carbon and nitrogen isotope measurements. This sampling scheme yields a resolution of about $300-1200 \mathrm{yr}$ for the isotope records at both sites. The opal samples were cleaned according to the procedure given in (Singer and Shemesh, 1995). Various studies (Sigman et al., 1999; Crosta and Shemesh, 2002; Robinson et al., 2004) have shown that different cleaning protocols might affect the absolute values of diatom $\delta{ }^{15} \mathrm{~N}_{\mathrm{D}}$ because of the oxidation reagent that is used to remove bulk organic matter from the diatom frustules. Apparently, there is

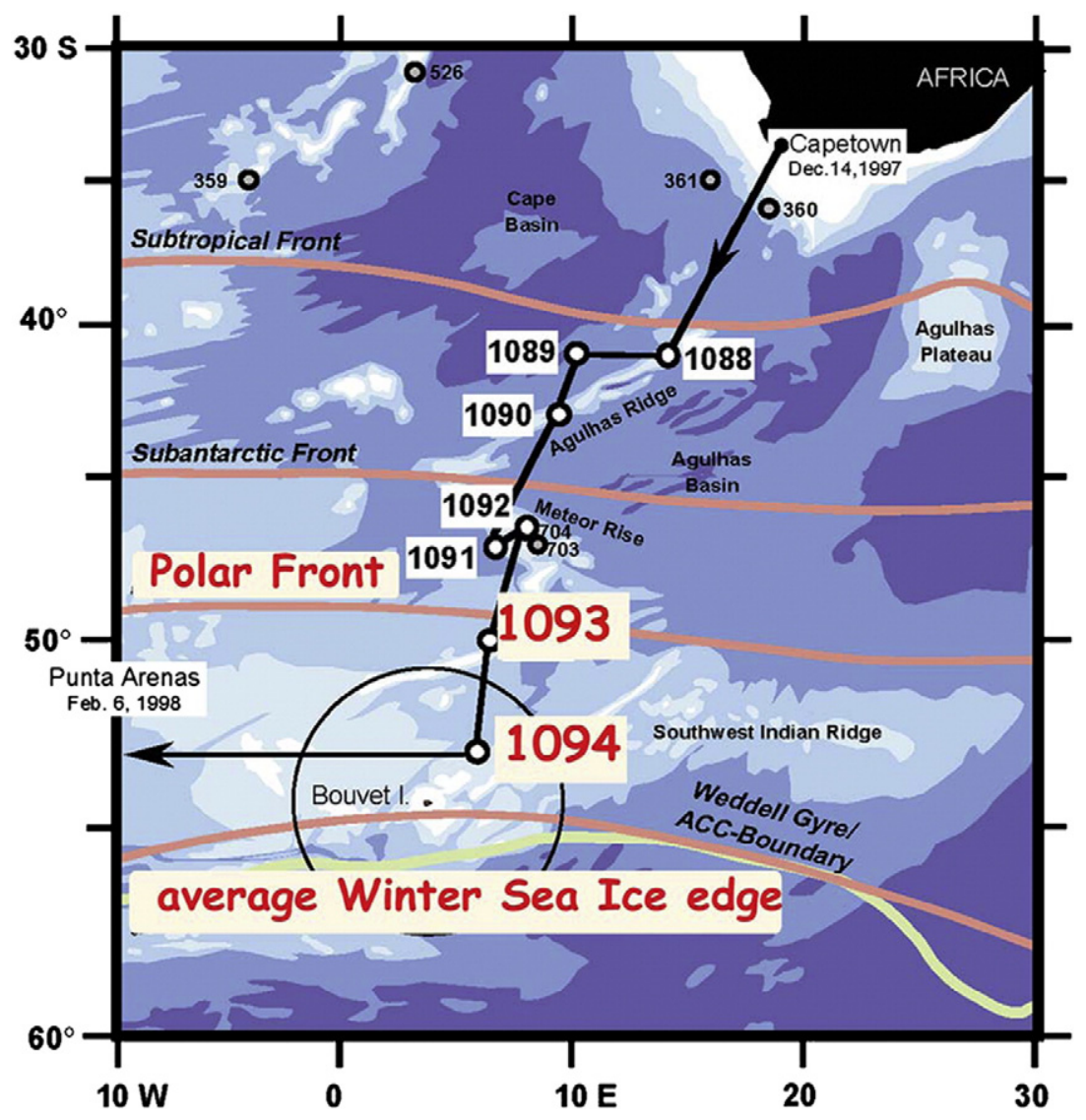

Figure 1. Location map of sites 1094 and 1093. 
a preferential leaching of diatom organic matter, although this was not proved directly by any of these studies. Therefore, our $\delta^{15} \mathrm{~N}_{D}$ records are derived from the residual organic matter protected by silica against oxidation with the $\mathrm{HClO}_{4}$ and $\mathrm{HNO}_{3}$ used to clean the samples. This analytical procedure also allows for direct comparison with previously published records in the Southern Ocean (Crosta and Shemesh, 2002; Schneider-Mor et al., 2005). The isotope measurements were performed on a Carlo Erba EA1110 elemental analyzer in line with a Finnigan MAT252 stable-isotope ratio mass spectrometer. The carbon and nitrogen isotopes were measured simultaneously from the same sample by peak jumping with a mean standard deviation of $0.19 \%$ and $0.28 \%$ for $\delta^{13} C_{D}$ and $\delta{ }^{15} N_{D}$, respectively. All results are reported relative to PDB for $\delta^{13} C_{D}$ and relative to air for $\delta^{15} \mathrm{~N}_{\mathrm{D}}$. We did not find a significant correlation between species assemblage and $\delta^{13} C_{D}$ in either site.

SSST and WSI were estimated by species counts and the application of transfer function techniques (Imbrie and Kipp, 1971). The SSST was calculated using 29 taxa or taxa groups which follow the taxonomic identification of Crosta et al. (2004).The winter sea-ice estimates were attained from the two sea-ice indicator species Fragilariopsis curta and Fragilariopsis cylindrus, (Gersonde and Zielinski, 2000). All records were resampled to create a uniform resolution of $1 \mathrm{ka}$ because SSST and WSI records do not have the same resolution as the isotope records. The resampling was performed using the Piecewise Cubic Hermite Interpolation Polynomial (PCHIP) which preserves the shape of the original data and respects monotonicity and convexity (Fritsch and Carlson, 1980).

\section{Results}

The down-core records of ODP Sites 1094 and 1093 document seven terminations over the last $660 \mathrm{ka}$. There is a large variability in pattern, magnitude, and length among the proxies across the terminations. Six terminations at ODP Site 1094 (TII-TVII) and seven terminations at ODP Site 1093 (TI-TVII) were studied (Fig. 2). We also use the data pertaining to TI from core TNO57-13-PC4 $\left(53^{\circ} 2^{\prime} \mathrm{S}, 5^{\circ} 1^{\prime}\right.$ E), which is located in close proximity to ODP Site $1094\left(53^{\circ} 10.8^{\prime} \mathrm{S}\right.$, $5^{\circ} 7.8^{\prime} \mathrm{E}$ ) (Shemesh et al., 2002).

The isotope records from ODP 1094 and TN057-13-PC4 show glacial-interglacial transitions with relatively large magnitudes of $4-6 \%$ and $1.8-4.6 \%$ of $\delta^{13} C_{D}$ and $\delta{ }^{15} \mathrm{~N}_{\mathrm{D}}$, respectively, for five out of the seven terminations (TI, TII, TIV, TV, and TVII). The remaining terminations, TIII and TVI, have a small magnitude of about $1.5 \%$ for both $\delta^{13} C_{D}$ and $\delta{ }^{15} \mathrm{~N}_{\mathrm{D}}$ (Fig. 3IIa-VIIa and IIb-VIIb; Table 1 ).

The isotope records from ODP Site 1093 show three large transitions of $3.1-4.9 \%$ or $\delta^{13} C_{D}$ and $1.7-2.5 \%$ of $\delta^{15} \mathrm{~N}_{D}$ at TIV, TV, and TVII, (Fig. 4 IVa, Va and VIIa and IVb, Vb and VIIb; Table 2) and four small transitions of about $2 \%$ for $\delta^{13} \mathrm{C}_{\mathrm{D}}$ and $1 \%$ for $\delta^{15} \mathrm{~N}_{\mathrm{D}}$ at TI-TIII and TVI (Fig. 4 Ia-IIIa and Vla and Ib-IIIb and VIb). The SSST records from both sites, 1094 and 1093, display five large temperature shifts in the range of $3.1^{\circ}-5.5^{\circ} \mathrm{C}$ at TI-TV and a relatively small temperature change of $1.2-2.9^{\circ} \mathrm{C}$ at TVI and TVII (Figs. 3 IIc-Vc and 4 Ic-Vc; Tables 1 and 2).

The terminations differ also with respect to their duration and the time it took for each proxy to complete the full transition from glacial

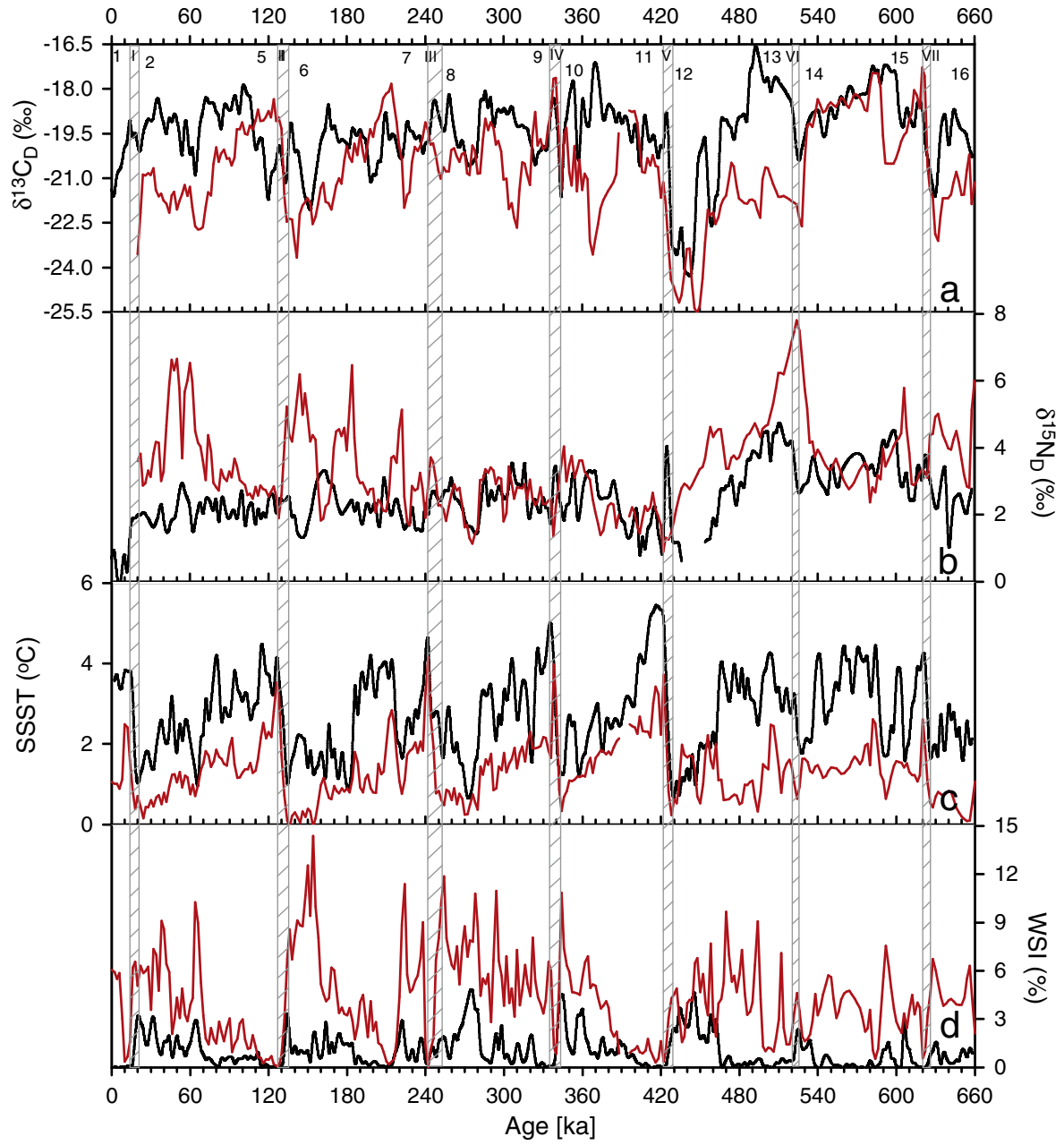

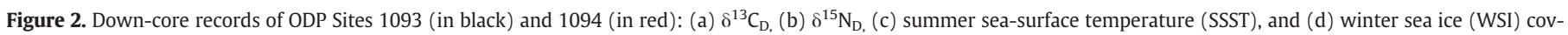
erage. The records were resampled at 1 ka intervals. The light gray lines mark Terminations. 


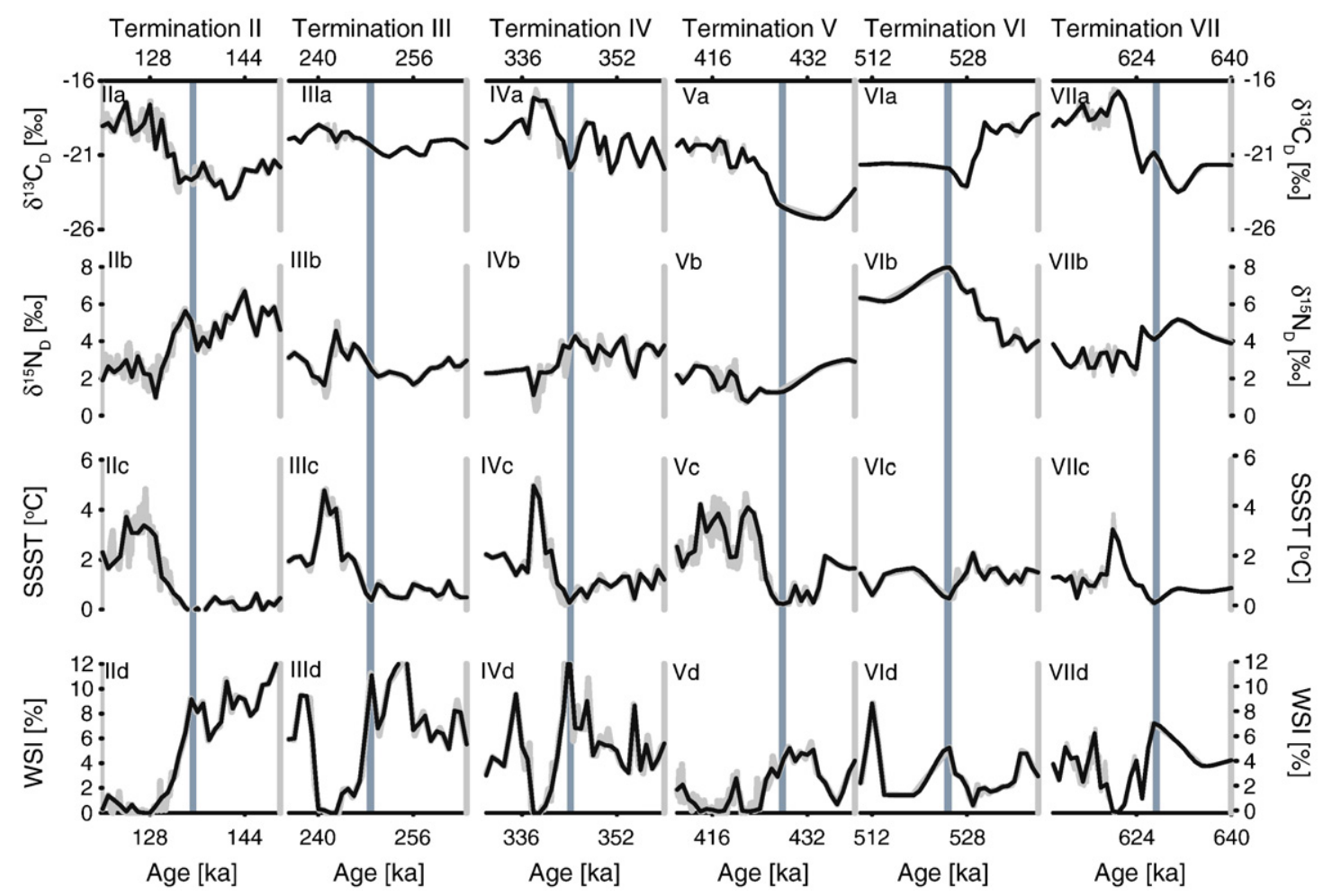

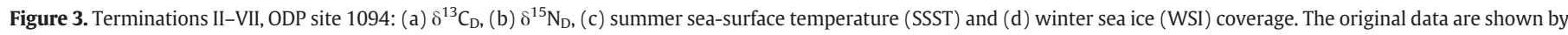
a gray line; the data resampled at 1 ka intervals are shown by a black line. The Termination onset set by the SSST and is marked by gray vertical lines.

to interglacial values (Figs. 3-4, Tables 1-2). The durations of the terminations can be directly compared only if the sedimentation rates are comparable and large enough to avoid bias stemming from the sampling resolution. Sedimentation rates at ODP Site 1094 are about $23 \mathrm{~cm} / \mathrm{ka}$ in four out of six terminations; therefore, the durations of these terminations (TII-TV) can be calculated and compared. On the other hand, TVI and TVII have much lower sedimentation rates, only $9 \mathrm{~cm} / \mathrm{ka}$, and their durations cannot be compared directly to those of the other Terminations. The records from ODP 1093 show a similar sedimentation rate $(20 \mathrm{~cm} / \mathrm{ka})$ throughout the last $660 \mathrm{ka}$; therefore, the durations of all the terminations can be compared. The duration of the terminations is calculated from the age of the last minimum point of the glaciation to the age of the first point of the interglaciation. The durations of the transitions from glacial to interglacial periods, in all proxies and all terminations, ranged from 2 to $10 \mathrm{ka}$ (Figs. 3-4, Tables 1-2). Termination V at ODP Site 1094 had the longest transition times: $10 \mathrm{ka}$ and $12 \mathrm{ka}$ for $\delta{ }^{13} C_{\mathrm{D}}$ and $\delta{ }^{15} \mathrm{~N}_{\mathrm{D}}$, respectively (Fig. 3Va, b).

In order to study the sequences of events in the records of sites 1093 and 1094, we compared the onset points of all proxies to the SSST onset point and determined the leads and lags in relation to SSST (Figs. 3-4; Tables 1 and 2). The onset point for the $\mathrm{C}$ and $\mathrm{N}$ isotopes is at the base of the largest change that occurred in each period, adjacent to the SSST change. In terms of 'absolute' age, the time of onset at ODP 1094 differs from that at ODP 1093 by 0-3 ka (Tables 1-2). This most likely originates from the uncertainties in the age model used to date the sites. Thus, we consider it to be an age model artifact rather than a true observation. All proxy records were resampled at $1 \mathrm{ka}$ intervals to obtain equal resolution and to mask background noise. Therefore, at least a 1 ka difference between the proxies is within the noise limit (Tables 1-2).

The sequence of events during Terminations I, II, and VI in sites 1093 and 1094 show that SSST and WSI lead the $\delta{ }^{13} C_{D}$ and $\delta{ }^{15} N_{D}$ onsets or that the four indicators change simultaneously within the noise limit (Figs. 3-4). During TVI at site 1094, SSST, WSI, and $\delta{ }^{15} \mathrm{~N}_{\mathrm{D}}$ change simultaneously, but $\delta^{13} C_{D}$ leads the other records by $2 \mathrm{ka}$.
However, since the total change in $\delta{ }^{13} C_{D}$ is $\sim 1 \%$, we consider this lead insignificant (Fig. 3VIa-d).

In TVII, the onset point for glacial-interglacial change in $\delta^{13} C_{D}$ and $\delta^{15} \mathrm{~N}_{\mathrm{D}}$ values at site 1094 is $631 \mathrm{ka}$, although it seems that the main jump started at $625 \mathrm{ka}$, because the wiggle at $627 \mathrm{ka}$ is determined by only one point and is not consistent with the record from site 1093 (Fig. 3VII). Terminations V and VII at sites 1094 and 1093 show $\delta^{13} C_{D}$ and $\delta^{15} N_{D}$ significantly leading SSST and WSI by 4-9 ka (Figs. $3 \mathrm{~V}$ and VII and $4 \mathrm{~V}$ and VII). At TIII, the $\delta^{13} \mathrm{C}_{\mathrm{D}}$ records of both sites show a 2-3 ka lead on SSST and WSI (Figs. 3III and 4III). The $\delta^{15} \mathrm{~N}_{\mathrm{D}}$ record from site 1094 leads the change by $1 \mathrm{ka}$ while the $\delta^{15} \mathrm{~N}_{\mathrm{D}}$ of Site 1093 changes simultaneously with SSST and WSI (Figs. 3III and 4III). The total change in $\delta^{13} C_{D}$ before the SSST onset is between 0.2 and $0.6 \%$, which is $14-40 \%$ of the total transition for sites 1093 and 1094, respectively (Figs. 3IIIa and 4IIIa). The $\delta{ }^{15} \mathrm{~N}_{\mathrm{D}}$ record of site 1094 shows an enrichment trend in TIII instead of the depletion observed in all the other terminations (Fig. 3IIb-VIIb). Generally, TIV shows small isotopic changes across the transition. $\delta^{13} C_{D}$ and $\delta{ }^{15} N_{D}$ lead SSST by $1 \mathrm{ka}$ and WSI by $2 \mathrm{ka}$ at ODP Site 1093 and the total change before the SSST onset is $1.4 \%$ for $\delta^{13} C_{D}$ and $0.8 \%$ for $\delta^{15} \mathrm{~N}_{\mathrm{D}}$ (Figs. 3VI and 4VI). However, at site $1094 \delta^{13} \mathrm{C}_{\mathrm{D}}$ changes simultaneously with SSST and WSI but $\delta^{15} \mathrm{~N}_{\mathrm{D}}$ leads their change by $1 \mathrm{ka}$ with a total change of $0.8 \%$ in the $\delta^{15} \mathrm{~N}_{\mathrm{D}}$ record before the SSST onset (Fig. 3VIa).

\section{Discussion}

We focus on two aspects of the seven terminations recorded at ODP sites 1093 and 1094: the first is the magnitude of the change of each proxy across the termination, from the glacial value to the interglacial value; and the second is the sequence of events across the termination, examining leads and lags among the proxies. The accuracy of the absolute age of each termination is irrelevant to the scope of this discussion since the records are internally consistent after being sampled and processed from the same depths in the cores. 
Table 1

Site 1094 Terminations. The glacial-interglacial variation presented for each Termination was calculated from the 1 ka resampled records. Signal intensity and length were measured from the last glacial value to the first interglacial value. Termination I data are from the Shemesh et al., 2002. The lead /lag of all the proxies are determined relative to the SSST onset age. Lead has a positive sign and lag has a negative sign.

\begin{tabular}{|c|c|c|c|c|}
\hline Site 1094 & $\delta^{13} C_{D}(\%)$ & $\delta^{15} \mathrm{~N}_{\mathrm{D}}(\%)$ & $\operatorname{SSST}\left({ }^{\circ} \mathrm{C}\right)$ & WSI \\
\hline \multicolumn{5}{|l|}{$\begin{array}{l}\text { Termination I from } \\
\text { [Shemesh et al., 2002] }\end{array}$} \\
\hline Signal intensity & $3.9 \% \circ \pm 0.15$ & $3.4 \% \circ \pm 0.25$ & $4.7^{\circ} \mathrm{C} \pm 0.6$ & 4 \\
\hline Signal length & 4 ka & $2 \mathrm{ka}$ & $8 \mathrm{ka}$ & 3 ka \\
\hline Onset age & $19 \mathrm{ka}$ & $18 \mathrm{ka}$ & $19 \mathrm{ka}$ & $19 \mathrm{ka}$ \\
\hline $\begin{array}{l}\text { Lead/lag in relation to } \\
\text { SSST onset (ka) }\end{array}$ & 0 & -1 & 0 & 0 \\
\hline \multicolumn{5}{|l|}{ Termination II } \\
\hline Signal intensity & $5.3 \% \circ \pm 0.15$ & $4.6 \% \circ \pm 0.25$ & $3.4^{\circ} \pm 0.6$ & 9 \\
\hline Signal length & $5 \mathrm{ka}$ & $5 \mathrm{ka}$ & $8 \mathrm{ka}$ & 7 ka \\
\hline Onset age & $133 \mathrm{ka}$ & $134 \mathrm{ka}$ & $135 \mathrm{ka}$ & $135 \mathrm{ka}$ \\
\hline $\begin{array}{l}\text { Lead/lag in relation to } \\
\text { SSST onset (ka) }\end{array}$ & -2 & -1 & 0 & 0 \\
\hline \multicolumn{5}{|l|}{ Termination III } \\
\hline Signal intensity & $1.6 \% \circ \pm 0.15$ & $1.7 \% \circ \pm 0.25$ & $3.7^{\circ} \mathrm{C} \pm 0.6$ & 11 \\
\hline Signal length & $7 \mathrm{ka}$ & $4 \mathrm{ka}$ & $6 \mathrm{ka}$ & $6 \mathrm{ka}$ \\
\hline Onset age & $252 \mathrm{ka}$ & $250 \mathrm{ka}$ & $249 \mathrm{ka}$ & $249 \mathrm{ka}$ \\
\hline $\begin{array}{l}\text { Lead/lag in relation to } \\
\text { SSST onset (ka) }\end{array}$ & +3 & +1 & 0 & 0 \\
\hline \multicolumn{5}{|l|}{ Termination IV } \\
\hline Signal intensity & $4.5 \% \circ \pm 0.15$ & $2 \% \pm 0.25$ & $4.2^{\circ} \mathrm{C} \pm 0.6$ & 13 \\
\hline Signal length & $4 \mathrm{ka}$ & $4 \mathrm{ka}$ & $5 \mathrm{ka}$ & 4 ka \\
\hline Onset age & $344 \mathrm{ka}$ & $345 \mathrm{ka}$ & $344 \mathrm{ka}$ & $344 \mathrm{ka}$ \\
\hline $\begin{array}{l}\text { Lead/lag in relation to } \\
\text { SSST onset (ka) }\end{array}$ & 0 & +1 & 0 & 0 \\
\hline \multicolumn{5}{|l|}{ Termination V } \\
\hline Signal intensity & $4 \% ॰ \pm 0.15$ & $1.6 \% \circ \pm 0.25$ & $3.9^{\circ} \mathrm{C} \pm 0.6$ & 5 \\
\hline Signal length & $10 \mathrm{ka}$ & $9 \mathrm{ka}$ & $6 \mathrm{ka}$ & $5 \mathrm{ka}$ \\
\hline Onset age & $433 \mathrm{ka}$ & $436 \mathrm{ka}$ & $427 \mathrm{ka}$ & $429 \mathrm{ka}$ \\
\hline $\begin{array}{l}\text { Lead/lag in relation to } \\
\text { SSST onset (ka) }\end{array}$ & +5 & +8 & 0 & 0 \\
\hline \multicolumn{5}{|l|}{ Termination VI } \\
\hline Signal Intensity & $1 \% \pm \pm 0.15$ & $1.7 \% \circ \pm 0.25$ & $1.2^{\circ} \mathrm{C} \pm 0.6$ & 4 \\
\hline Signal Length & - & - & - & - \\
\hline Onset age & $527 \mathrm{ka}$ & $525 \mathrm{ka}$ & $525 \mathrm{ka}$ & $525 \mathrm{ka}$ \\
\hline $\begin{array}{l}\text { Lead/lag in relation to } \\
\text { SSST onset (ka) }\end{array}$ & +2 & 0 & 0 & 0 \\
\hline \multicolumn{5}{|l|}{ Termination VII } \\
\hline Signal intensity & $6.2 \% ॰ \pm 0.15$ & $2.6 \% \_ \pm 0.25$ & $2.9^{\circ} \mathrm{C} \pm 0.6$ & 7 \\
\hline Signal length & - & - & - & - \\
\hline Onset age & $631 \mathrm{ka}$ & $631 \mathrm{ka}$ & $627 \mathrm{ka}$ & $627 \mathrm{ka}$ \\
\hline $\begin{array}{l}\text { Lead/lag in relation to } \\
\text { SSST onset (ka) }\end{array}$ & +4 & +4 & 0 & 0 \\
\hline
\end{tabular}

\section{Termination magnitude}

Our records reveal that the terminations can be classified according to their magnitude. The large magnitude terminations are defined by an evident difference in all proxies between glacial and interglacial periods (Fig. 3: terminations I, II, IV, V and VII; Fig. 4: terminations IV, $\mathrm{V}$, and VII) while the weak terminations are characterized by a small transition between the glacial and the interglacial periods (Fig. 3: terminations III and VI; Fig. 4: terminations I-III and VI).

From a global perspective, there are large differences in temperature and gas content between glacial and interglacial periods over the last five terminations (e.g.: EPICA community members, 2004; Cortese et al., 2007; Crundwell et al., 2008) in ice cores and the marine foraminiferal isotope records (e.g.: Raymo, 1997; Lisiecki and Raymo, 2005; Crundwell et al., 2008). The large magnitude terminations at sites 1093 and 1094 also show a large temperature contrast of $\sim 4^{\circ} \mathrm{C}$ between glacial and interglacial periods (Figs. 3Ic-Vc and $4 \mathrm{Ic}-\mathrm{Vc}$ ). The $\mathrm{C}$ and $\mathrm{N}$ isotope records of the large-magnitude terminations show clear differences between the climatic modes, suggesting changes in productivity level and nutrient availability (Fig. 3IIa, b, IVa,b, Va,b and VIIa,b and Fig. 4IVa,b Va,b and VIIa,b); (Francois et al., 1997; Crosta and Shemesh, 2002; Schneider-Mor et al., 2005; Robinson and Sigman, 2008). The large-magnitude terminations suggest that the global glacial conditions were sufficient to affect temperature and oceanic circulation (Raymo, 1997; Rutberg et al., 2000; Jouzel et al., 2007) at these sites.

The isotopic records of $\delta^{13} C_{D}$ and $\delta^{15} N_{D}$ show five terminations with large differences between the glacial and interglacial values. Two weak terminations, TIII and TVI, are seen at site 1094 and four weak terminations, TI-TIII and TVI, are observed at site 1093 (Tables 1-2). The weak terminations, which are characterized by a relatively small change in the $\delta^{13} C_{D}$ and $\delta{ }^{15} N_{D}$ records, might suggest higher levels of primary production and nutrient utilization during weak glacial periods, compared to full glacial condition modes (Figs. 3IIa,b and VIa,b and 4I-IIIa,b and Vla,b). The weak terminations I-TIII at site 1093 (Fig. 4I-IIIa-b) are probably associated with the Polar Front influence, which maintained high nutrient levels at this site during the glacial periods between 0 and $260 \mathrm{ka}$, and masked the effects of global climate change in this region (Schneider-Mor et al., 2008). The SSST and WSI records in both cores show a small change during TVI and TVII, similar to and in accordance with the global climate signals (Figs. 3VI3VIIc-d and 4VI-VIIc-d); (e.g.: Crundwell et al., 2008; EPICA community members, 2004). The small glacial-interglacial temperature and sea-ice changes point to weak glacial periods, which resulted from glaciers advancing to a reduced extent (Raymo, 1997; Jouzel et al., 2007).

Termination VI is a weak termination in all proxies and in both cores 1094 and 1093. The proxy records at both sites correlate very well with the $\delta \mathrm{D}$ record of the EPICA Dome $\mathrm{C}$ ice core, which also exhibits a small contrast between glacial and interglacial periods between 740 and $450 \mathrm{ka}$ and indicates warmer glacial and colder interglacial periods (EPICA community members, 2004; Rothlisberger et al., 2008). Sediment cores from the Atlantic and Pacific Oceans recorded weak conditions at Termination VI as well, suggesting that the phenomenon was global (Raymo, 1997; Lisiecki and Raymo, 2005). This weak termination could be related to a global ice age that did not fully develop in the Northern and Southern hemispheres (e.g.:Raymo et al., 1997; Lisiecki and Raymo, 2005).

Alternatively, the weak termination at TVI could also have been influenced by the insolation transition in the Earth's orbit from a 41 ka obliquity cycle to a 100 ka eccentricity cycle, named the MidPleistocene Transition (MPT), which affected global climate. The MPT began 900 ka (Ruddiman et al., 1989; Raymo et al., 1997) and there is evidence that the transition period was prolonged until $\sim 450 \mathrm{ka}$. The early MPT period between 750 and 450 ka was characterized by low-amplitude $41 \mathrm{ka}$ obliquity-forced glacial-interglacial cycles, which were replaced progressively, in the later Pleistocene, by high-amplitude 100 ka cycles (Ruddiman et al., 1989; Mudelsee and Stattegger, 1997; EPICA community members, 2004; Raymo et al., 2004). Therefore, it is possible to relate the small magnitude of the SSST records at both sites during terminations VI and VII to the global influence of the MPT, in accordance with previous observations in the Pacific Ocean and the EPICA dome C ice core (Crundwell et al., 2008; Rothlisberger et al., 2008). However, it is interesting to note that the climate conditions were distinctive enough to generate a significant contrast in the $\delta^{13} C_{D}$ and $\delta{ }^{15} \mathrm{~N}_{\mathrm{D}}$ records, implying a change in productivity and nutrient utilization towards a full glacial mode at TVII (Fig. 3VIIa,b and Fig. 4VIIa,b).

Termination III exhibits a unique pattern at both ODP sites. The isotope records, $\delta{ }^{13} C_{D}$ and $\delta{ }^{15} \mathrm{~N}_{\mathrm{D}}$, show a relatively small change across the termination while the SSST records show almost a full 


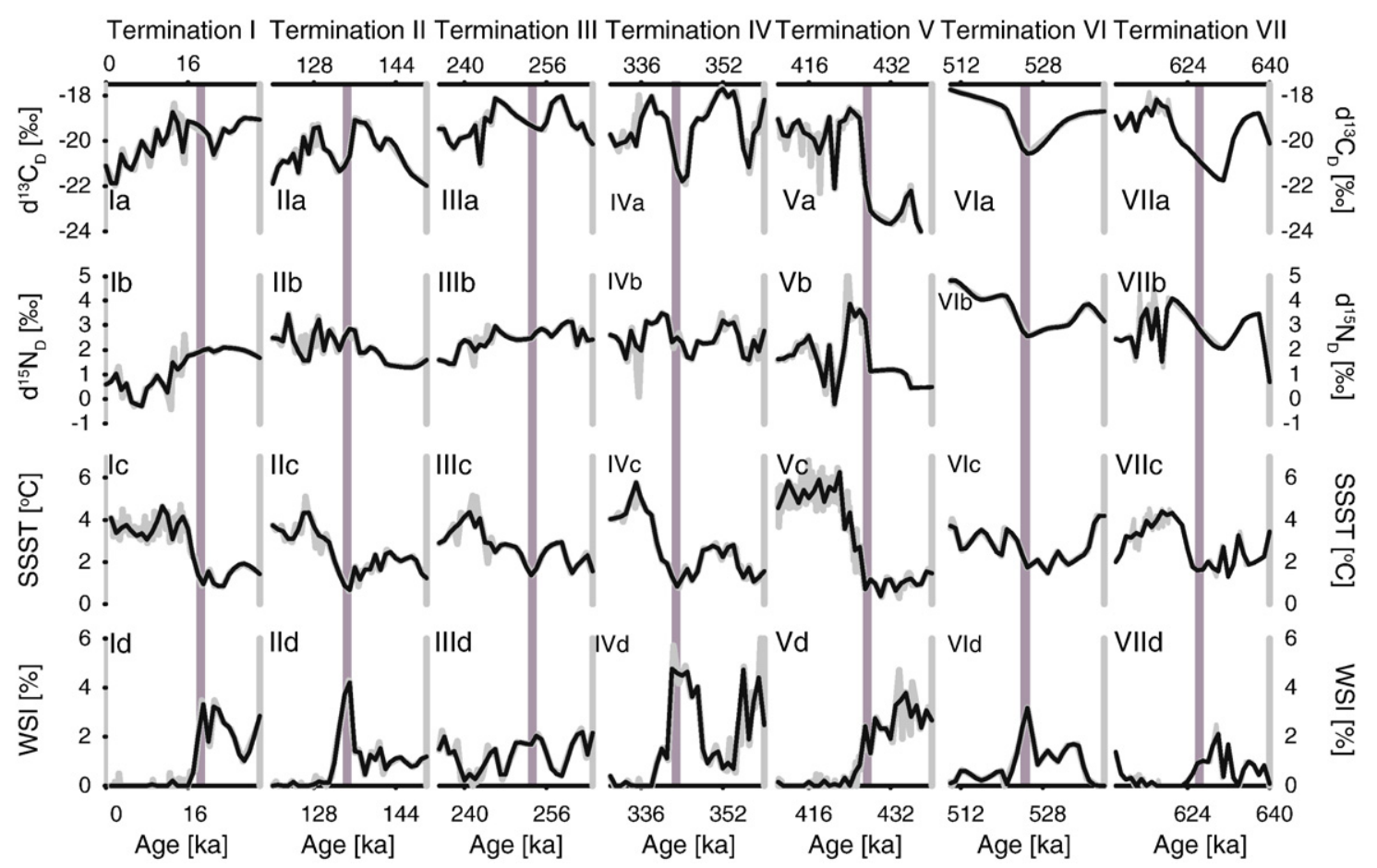

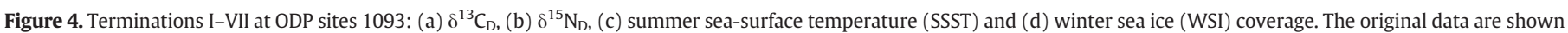
by the gray line; the data resampled at 1 ka intervals are shown by the black line. The Termination onset set by the SSST is marked by gray vertical lines.

glacial-interglacial change (Figs. 3III and 4III). The relatively small change in $\delta^{13} C_{D}$ and $\delta{ }^{15} \mathrm{~N}_{\mathrm{D}}$ suggests that higher productivity prevailed across MIS 8 and TIII at sites 1094 and 1093. Based on sediment cores from the North Atlantic, Equatorial Atlantic and the Pacific, Termination III was previously described as a weak transition and MIS 8 was also considered as a weak global glacial period (Raymo, 1997; Helmke and Bauch, 2003). The weak glacial mode in both sites may points to a link between the North Atlantic Ocean and the Southern Ocean sites and the high productivity observed in both sites suggests an increase in nutrient supply to the region. Carbon isotope records from benthic and planktonic foraminifera suggest that the Southern Ocean was repeatedly stratified at depths of $>2500 \mathrm{~m}$ during the first four glacial cycles (Hodell et al., 2003; Charles et al., 2010). It was also shown that waters above $2100 \mathrm{~m}$ at the Southern Ocean were ventilated and could have been influenced by the Glacial North Atlantic Intermediate Water (GNAIW) flow (Oppo and Lehman, 1993; Oppo and Horowitz, 2000). However, the ventilated Atlantic Water was depleted in nutrient and cannot be considered as a nutrient source (Oppo and Horowitz, 2000).

An alternative source of nutrients to the Southern Ocean's surface water during TIII could have been Subantarctic surface water (Sigman and Boyle, 2000). The foraminifera records from that region show that the Atlantic sector of the Subantarctic experienced an excess of nutrients in its surface water, possibly originating from upwelled intermediate water during glacial periods (Ninnemann and Charles, 1997, 2002). This nutrient excess in the Subantarctic region could have supplied the nutrients to the siliceous belt. Such a source could have supported the relatively higher productivity observed across MIS 8 and TIII at sites 1094 and 1093 and may shed light on regional nutrient supply and transport. Glacial temperatures during MIS 8 were not significantly different from all other glacial temperatures both in the Vostok ice and Dome C records (Petit et al., 1999; EPICA community members, 2004) and in sites 1093 and 1094. Therefore, we conclude that the high productivity during glacial MIS 8 did not result from warmer glacial conditions in the Southern Ocean but mainly from changes in nutrient supply.

\section{Sequence of events}

The sequence of events at each site and during each glacial cycle was determined by analyzing the transition period from glacial to interglacial conditions. We were able to measure the transition length, intensity, as well as leads and lags between the proxies since our records are internally consistent and are not biased by the age model that was assigned to the cores.

We obtained information on the processes governing surface water characteristics during climate transition in the Southern Ocean by establishing the temporal resolution between the physical parameters (SSST, WSI) and the nutrient utilization and productivity parameters $\left(\delta^{13} C_{D}, \delta^{15} N_{D}\right)$. On the basis of the sequence of events in Termination I (Shemesh et al., 2002), it was reasonable to expect that SSST and WSI would lead the change, followed by subsequent changes in $\delta^{13} C_{D}$ and $\delta^{15} N_{D}$, which represent the reorganization of the nutrient regimes. Indeed, in site 1094 and site 1093, three out of seven terminations, namely, TI, TII and TVI, follow this pattern (Figs. 3II and VI and 4I, II and VI; Tables 1 and 2). However, the other four Terminations, TIII-TV and TVII, show that $\delta^{13} C_{D}$ and $\delta{ }^{15} \mathrm{~N}_{\mathrm{D}}$ lead SSST and WSI changes by 2-9 ka (Figs. 3III-V, VII and 4III-V, VIII).

At TI, TII and TVI, the lead of SSST and WSI over the isotope records and nutrient cycling suggests that productivity and nutrient availability in the Southern Ocean increased only after the sea ice melted and the high sea-surface temperatures stabilized (Shemesh et al., 2002). Previous studies showed that nutrient availability in the Southern Ocean is limited by stratification of the Southern Ocean and by reduction of NADW flow during glacial periods (Francois et al., 1997; Sigman et al., 1999; Toggweiler, 1999; Crosta and Shemesh, 2002). Termination I at site 1094 shows a simultaneous change of SSST, WSI and $\delta^{13} \mathrm{C}_{\mathrm{D}}$, while $\delta^{15} \mathrm{~N}_{\mathrm{D}}$ lags by $1 \mathrm{ka}$ (Table 1 ) (Shemesh et al., 2002). This suggests that productivity was mainly affected by seaice cover, while the nutrient concentration increase occurred over a longer time frame because of the influence of NADW, which has a turnover of about $1 \mathrm{ka}$ (Shin et al., 2003). Termination II at site 1094 shows SSST and WSI leading $\delta{ }^{13} C_{D}$ by 2 ka and $\delta{ }^{15} \mathrm{~N}_{\mathrm{D}}$ by $1 \mathrm{ka}$ 
Table 2

Site1093 Terminations. The glacial-interglacial variation presented for each Termination was calculated from the $1 \mathrm{ka}$ resampled records. Signal intensity and length were measured from the last glacial value to the first interglacial value. The lead /lag of all the proxies are determined relative to the SSST onset age. Lead has a positive sign and lag has a negative sign.

\begin{tabular}{|c|c|c|c|c|}
\hline Site 1093 & $\delta^{13} C_{D}$ & $\delta^{15} \mathrm{~N}_{\mathrm{D}}$ & SSST & WSI \\
\hline \multicolumn{5}{|l|}{ Termination I } \\
\hline Signal intensity & $1.5 \% \circ \pm 0.2$ & $0.2 \% \_ \pm 0.3$ & $3.1^{\circ} \mathrm{C} \pm 0.6$ & 3.3 \\
\hline Signal length & $8 \mathrm{ka}$ & $1 \mathrm{ka}$ & $4 \mathrm{ka}$ & 3 ka \\
\hline Onset age & $15 \mathrm{ka}$ & $16 \mathrm{ka}$ & 19 ka & $19 \mathrm{ka}$ \\
\hline $\begin{array}{l}\text { Lead/lag in relation } \\
\text { to SSST onset (ka) }\end{array}$ & -4 & -3 & 0 & 0 \\
\hline \multicolumn{5}{|l|}{ Termination II } \\
\hline Signal Intensity & $1.5 \% \circ \pm 0.2$ & $0.7 \% \circ \pm 0.3$ & $3.6^{\circ} \mathrm{C} \pm 0.6$ & 3.6 \\
\hline Signal Length & $4 \mathrm{ka}$ & $2 \mathrm{ka}$ & $8 \mathrm{ka}$ & $4 \mathrm{ka}$ \\
\hline Onset age & $133 \mathrm{ka}$ & $133 \mathrm{ka}$ & $135 \mathrm{ka}$ & $135 \mathrm{ka}$ \\
\hline $\begin{array}{l}\text { Lead/lag in relation } \\
\text { to SSST onset (ka) }\end{array}$ & -2 & -2 & 0 & 0 \\
\hline \multicolumn{5}{|l|}{ Termination III } \\
\hline Signal intensity & $1.4 \% \circ \pm 0.2$ & $0.5 \% \circ \pm 0.3$ & $2.7^{\circ} \mathrm{C} \pm 0.6$ & 2 \\
\hline Signal length & $9 \mathrm{ka}$ & $6 \mathrm{ka}$ & $10 \mathrm{ka}$ & $6 \mathrm{ka}$ \\
\hline Onset age & $255 \mathrm{ka}$ & $253 \mathrm{ka}$ & $253 \mathrm{ka}$ & $254 \mathrm{ka}$ \\
\hline $\begin{array}{l}\text { Lead/lag in relation } \\
\text { to SSST onset (ka) }\end{array}$ & +2 & 0 & 0 & +1 \\
\hline \multicolumn{5}{|l|}{ Termination IV } \\
\hline Signal intensity & $3 \% \pm 0.2$ & $1.7 \% \circ \pm 0.3$ & $4.2^{\circ} \mathrm{C} \pm 0.6$ & 4.7 \\
\hline Signal length & $4 \mathrm{ka}$ & $4 \mathrm{ka}$ & $7 \mathrm{ka}$ & 4 ka \\
\hline Onset age & 344 ka & $345 \mathrm{ka}$ & $343 \mathrm{ka}$ & $342 \mathrm{ka}$ \\
\hline $\begin{array}{l}\text { Lead/lag in relation } \\
\text { to SSST onset (ka) }\end{array}$ & +1 & +2 & 0 & -1 \\
\hline \multicolumn{5}{|l|}{ Termination V } \\
\hline Signal intensity & $4.6 \% ॰ 0.2$ & $2.5 \% \circ \pm 0.3$ & $5.5^{\circ} \mathrm{C} \pm 0.6$ & 2.4 \\
\hline Signal length & $6 \mathrm{ka}$ & $2 \mathrm{ka}$ & $5 \mathrm{ka}$ & 3 ka \\
\hline Onset age & $432 \mathrm{ka}$ & $428 \mathrm{ka}$ & $427 \mathrm{ka}$ & $427 \mathrm{ka}$ \\
\hline $\begin{array}{l}\text { Lead/lag in relation } \\
\text { to SSST onset (ka) }\end{array}$ & +5 & +1 & 0 & 0 \\
\hline \multicolumn{5}{|l|}{ Termination VI } \\
\hline Signal intensity & $1.9 \% \circ \pm 0.2$ & $1.6 \% \circ \pm 0.3$ & $1.3^{\circ} \mathrm{C} \pm 0.6$ & 3 \\
\hline Signal length & $4 \mathrm{ka}$ & $4 \mathrm{ka}$ & $4 \mathrm{ka}$ & 4 ka \\
\hline Onset age & $525 \mathrm{ka}$ & $525 \mathrm{ka}$ & $525 \mathrm{ka}$ & $525 \mathrm{ka}$ \\
\hline $\begin{array}{l}\text { Lead/lag in relation } \\
\text { to SSST onset (ka) }\end{array}$ & 0 & 0 & 0 & 0 \\
\hline \multicolumn{5}{|l|}{ Termination VII } \\
\hline Signal intensity & $3.2 \% ॰ 0.2$ & $2 \% \_ \pm 0.3$ & $2.7^{\circ} \mathrm{C} \pm 0.6$ & 1 \\
\hline Signal length & $10 \mathrm{ka}$ & $9 \mathrm{ka}$ & $5 \mathrm{ka}$ & $4 \mathrm{ka}$ \\
\hline Onset age & $630 \mathrm{ka}$ & $630 \mathrm{ka}$ & $626 \mathrm{ka}$ & $627 \mathrm{ka}$ \\
\hline $\begin{array}{l}\text { Lead/lag in relation } \\
\text { to SSST onset (ka) }\end{array}$ & +4 & +4 & 0 & +1 \\
\hline
\end{tabular}

(Fig. 3II; Table 1). MIS 6 is known as a strong glacial in the Southern Ocean (Becquey and Gersonde, 2003; Crundwell et al., 2008), and it is reasonable to assume that it took more time for the biological system to restore. Indeed, SSST and WSI lead $\delta^{13} \mathrm{C}_{\mathrm{D}}$ and $\delta{ }^{15} \mathrm{~N}_{\mathrm{D}}$ in TI and TII at site 1093 (Fig. 4I and II). However, at site 1093, the weak isotope signals are related to that site's proximity to the Polar Front and its influence on nutrient cycling at this particular location (Schneider-Mor et al., 2008).

At TIII and TIV, $\delta{ }^{13} C_{D}$ and $\delta{ }^{15} N_{D}$ lead changes in the SSST and WSI records by $1-3 \mathrm{ka}$, however the total isotopic change is $<1 \%$ 。 (Figs. 3III, 3VI and 4III, 4VI; Tables 1 and 2). Termination III at site 1094 shows a small change of $\sim 0.5 \%$ in the $\delta^{13} C_{D}$ and $\delta{ }^{15} \mathrm{~N}_{\mathrm{D}}$ records, which leads the onset of SSST and WSI. Termination III at Site 1093 is one of three small Terminations (TI-TIII) that were influenced by the polar-front location (Schneider-Mor et al., 2008; Fig. 4III). Therefore, at both sites, TIII suggests a faster recovery of productivity and nutrient cycling, although SSST and WSI show full-magnitude changes (Figs. 3III-3IV, 4III-4IV). Termination IV shows that $\delta^{13} C_{D}$ leads SSST and WSI by 1 ka at site 1093 and changes simultaneously with them at site 1094 , while $\delta^{15} \mathrm{~N}_{\mathrm{D}}$ leads SSST and WSI by 1-2 ka at both sites (Figs. 3IV and 4IV). As suggested above, higher productivity and nutrient levels could have been sustained at TIII and TIV prior to the onset of interglacial SSST values by the Subantarctic water shows evidence of a high nutrient load, it could also be the source of nutrients to sites 1093 and 1094 (Sigman and Boyle, 2000). Possible support for this scenario comes from the $\delta^{15} \mathrm{~N}_{\mathrm{D}}$ record of site 1094 during TIII, which shows enrichment during the glacial-interglacial transition, an opposite trend to the depletion observed during all other Terminations (Fig. 3IIIb). The $\delta^{15} \mathrm{~N}_{\mathrm{D}}$ isotope enrichment is indicative of a weaker glacial coupled with higher productivity that had consumed a large proportion of the nutrients and produced an enriched isotopic signal.

During TV and TVII, the $\delta^{13} \mathrm{C}_{\mathrm{D}}$ and $\delta^{15} \mathrm{~N}_{\mathrm{D}}$ records at both sites lead SSST and WSI by $4-8$ ka (Figs. $3 \mathrm{~V}$, VII and $4 \mathrm{~V}$. VII; Tables 1 and 2 ). The $\mathrm{C}$ and $\mathrm{N}$ isotopes during TV and TVII show changes of $0.8-2 \%$ and $0.9-2.1 \%$, respectively, before the onset of the temperature change. However, the long lag of the physical parameters and the large change in the carbon and nitrogen isotopes that characterize both TV and TVII require a different scenario that might be related to the MPT. Previous studies showed that, during the MPT, climatic conditions were different from those of the following four strong glacialinterglacial cycles (MIS 1-10) (Hall et al., 2001; EPICA community members, 2004; Crundwell et al., 2008). Therefore, it is possible that TV and TVII were triggered by a different mechanism than the younger terminations, namely, TI-TIV. Our present analysis reveals that ODP sites 1094 and 1093 had reduced winter sea-ice cover, a smaller temperature amplitude, and heavier $\delta^{13} C_{D}$ and $\delta{ }^{15} N_{D}$ values from 440 to $660 \mathrm{ka}$ compared to the younger period of $0-440 \mathrm{ka}$ (Figs. 3V, 3VII and 4V, 4VII). Studies showed there was a decrease in deep-water formation in the Southern Ocean during the MPT periods of 480-860 ka, suggesting a weaker thermohaline circulation (Raymo et al., 1997; Hall et al., 2001; Crundwell et al., 2008). In addition, there was less contrast between glacial and interglacial temperatures in Antarctica during that time interval (EPICA community members., 2004), and the dust concentration in the ice cores was reduced by about 30\% during the mid-Pleistocene periods (Winckler et al., 2005; Wolff et al., 2006; Lambert et al., 2008). The Arctic region was free of interglacial seasonal ice during the MPT (Cronin et al., 2008). All these observations support the assumption that the climate of the mid-Pleistocene transition was different from that of the last $450 \mathrm{ka}$. The main climatic processes and controls that dominated during the MPT period are still unknown but are probably reflected in the Southern Ocean records.

Our study shows that not all the Terminations have a similar sequence of events during the past $660 \mathrm{ka}$. More specifically, it reveals that the Southern Ocean system exhibited complex behavior and more than a single climatic control and response mechanism throughout the Pleistocene. One mode, which is represented by TI, TII and TVI, shows SSST and WSI leading the isotope records. This suggests a scenario in which summer sea-surface temperature increases and the melting of sea ice precede changes in the productivity and nutrient systems. Another mode, which is reflected in TIII, TIV, TV, and TVII, shows $\delta^{13} C_{D}$ and $\delta^{15} \mathrm{~N}_{\mathrm{D}}$ leading the change, followed by SSST and WSI, which suggests the interplay of several mechanisms discussed above. The sediment records also show that the Southern Ocean did not respond monotonically to glacial-interglacial transitions during the Pleistocene. The differences between the terminations emphasize the complexity of climate transition in comparison to the simplified scenarios that models provide. It is not clear why the physical parameters led the biological parameters in several terminations and the opposite occurred in other terminations. This phenomenon is apparently connected to high nutrient load at the Subantarctic water (at least at during TIII and TIV), and to the influence of the MPT through a weaker thermohaline circulation, and the 
reorganization of currents in the Subantarctic region (at TV and TVII) (Hall et al., 2001; Crundwell et al., 2008). This connection could imply that the main possible driver of the sequence of events during terminations and their amplitude were changes in the currents of the Subantarctic region. However, we note that the large variability in magnitude and timing cannot be assigned solely to reorganization of Subantarctic water because several time scales of leads and lags are presented in our results. This fact, together with the decoupling between the physical parameters (SSST and WSI) and nutrients (productivity and utilization), should be taken into account in constructing future models that attempt to represent the climatic transition in the Southern Ocean.

\section{References}

Anderson, R.F., Chase, Z., Fleisher, M.Q., Sachs, J., 2002. The Southern Ocean's biological pump during the Last Glacial Maximum. Deep-Sea Research Part II - Topical Studies in. Oceanography 49, 1909-1938.

Archer, D.E., Johnson, K., 2000. A model of the iron cycle in the ocean. Global Biogeochemical Cycles 14, 269-279.

Becquey, S., Gersonde, R., 2003. A 0.55-Ma paleotemperature records from the Subantarctic zone: implications for Antarctic Circumpolar Current development. Paleoceanography 18 2000PA000576.

Bianchi, C., Gersonde, R., 2004. Climate evolution at the last deglaciation: the role of the Southern Ocean. Earth and Planetary Science Letters 228, 407-424.

Broecker, W.S., 1984. Terminations. In: Berger, A., Imbrie, J., Hays, J.D., Kukla, G., Saltzman, E. (Eds.), Milankovitch and Climate. D. Reidel Publishing Company, New York, pp. 687-698.

Broecker, W.S., Denton, G.H., 1989. The role of ocean-atmosphere reorganizations in glacial cycle. Geochimica et Cosmochimica Acta 53, 2465-2501.

Broecker, W.S., Henderson, G.M., 1998. The sequence of events surrounding Termination II and their implications for the cause of glacial-interglacial $\mathrm{CO}_{2}$ changes. Paleoceanography 13, 352-364.

Broecker, W.S., Peng, T.H., 1989. The cause of the glacial to interglacial atmospheric $\mathrm{CO}_{2}$ change: a polae alkalinity hypotesis. Global Biogeochemical Cycles 3, 215-239.

Brzezinski, M.A., Pride, C.J., Franck, V.M., Sigman, D.M., Gruber, N., Rau, G.H., Coale, K.H. 2002. A switch from $\mathrm{Si}(\mathrm{OH})_{4}$ to $\mathrm{NO}_{3}$ depletion in the glacial Southern Ocean. Geophysical Research Letters 29, 1564. doi:10.1029/2001GL014349.

Charles, C.D., Pahnke, K., Zahn, R., Mortyn, P.G., Ninnemann, U., Hodell, D.A., 2010. Millennial scale evolution of the Southern Ocean chemical divide. Quaternary Science Reviews 29, 399-409.

Cortese, G., Abelmann, A., Gersonde, R., 2007. The last five glacial-interglacial transitions: a high-resolution 450,000-year record from the subantarctic Atlantic. Paleoceanography 22, PA4203. doi:10.1029/2007PA001457.

Cronin, T.M., Smith, S.A., Eynaud, F., Oregan, M., King, J., 2008. Quaternary Paleoceanograpy of the central Arctic based on Integrated Ocean Drilling Program Arctic Coring Expedition 302 foraminiferal assemblages. Paleoceanography 23, PA1S18. doi:10.1029/2007PA001484.

Crosta, X., Shemesh, A., 2002. Reconciling down core anticorrelation of diatom carbon and nitrogen isotopic ratios from the Southern Ocean. Paleoceanography 17, 1010 doi:10.1029/2000PA000565.

Crosta, X., Sturm, A., Armand, L., Pichon, J.J., 2004. Late Quaternary sea ice history in the Indian sector of the Southern Ocean as recorded by diatom assemblages. Marine Micropaleontology 50, 209-223.

Crundwell, M., Scott, G., Naish, T., Carter, L., 2008. Glacial-interglacial ocean climate variability from planktonic foraminifera during the Mid-Pleistocene transition in the temperate Southwest Pacific, ODP Site 1123. Palaeogeography, Palaeoclimatology, Palaeoecology 260, 202-229.

EPICA community members, 2004. Eight glacial cycles from an Antarctic ice core. Nature 429, 623-628.

Francois, R., Altabet, M.A., Yu, E.F., Sigman, D.M., Bacon, M.P., Frank, M., Bohrmann, G. Bareille, G., Labeyrie, L.D., 1997. Contribution of Southern Ocean surface-water stratification to low atmospheric $\mathrm{CO}_{2}$ concentrations during the last glacial period. Nature 389, 929-935.

Fritsch, F.N., Carlson, R.E., 1980. Monotone piecewise cubic interpolation. SIAM Journal on Numerical Analysis 17, 238-246.

Gersonde, R., Zielinski, U., 2000. The reconstruction of late Quaternary Antarctic sea-ice distribution - the use of diatoms as a proxy for sea-ice. Palaeogeography, Palaeoclimatology, Palaeoecology 162, 263-286.

Gersonde, R., Hodell, D.A., Blum, P., et al., 1999. Proceedings of the Ocean Drilling Program. Ocean Drilling Program, College Station, Texas. pp. online http://odp. pangaea.de/publications/177_IR/177ir.htm.

Gildor, H., Tziperman, E., 2000. Sea ice as the glacial cycles' climate switch: role of seasonal and orbital forcing. Paleoceanography 15, 605-615.

Gildor, H., Tziperman, E., 2001. A sea ice climate switch mechanism for the 100-kyr glacial cycles. Journal of Geophysical Research 106, 9117-9133.

Hall, I.R., McCave, I.N., Shackleton, N.J., Weedon, G.P., Harris, S.E., 2001. Intensified deep Pacific inflow and ventilation in Pleistocene glacial times. Nature 412, 809-812.

Hays, J.D., Imbrie, J., Shackleton, N.J., 1976. Variations in the Earth's orbit: pacemaker of ice ages. Science 194, 1121-1132.
Helmke, J.P., Bauch, H.A., 2003. Comparison of glacial and interglacial conditions between the polar and subpolar North Atlantic region over the last five climatic cycles. Paleoceanography 18, 1036. doi:10.1029/2002PA000794.

Hodell, D.A., Charles, C.D., Curtis, J.H., Mortyn, P.G., Ninnemann, U.S., Venz, K., 2003. In: Hodell, D.A.B. (Ed.), Data Report: Oxygen Isotope Stratigraphy of ODP Leg 177 Sites 1088, 1089, 1090, 1093, and 1094

Imbrie, J., Imbrie, J.Z., 1980. Modeling the climatic response of orbital variations. Science 207, 943-953.

Imbrie, J., Kipp, N.G., 1971. A new micropaleontological method for quantitative paleoclimotology: application to a Late Pleistocene Caribbean core. In: Tuerkian, K.K. (Ed.), The Late Cenozoic Glacial age. Yale University, New Haven, pp. 71-181.

Imbrie, J., Boyle, E.A., Clemens, S.C., Duffy, A., Howard, W.R., Kukla, G., Kutzbach, J., Martinson, D., McIntyre, A., Mix, A.C., Molfino, B., Morley, J.J., Peterson, L.C., Pisias, N.G., Prell, W.L., Raymo, M.E., Shackleton, N.J., Toggweiler, J.R., 1992. On the structure and origin of major glaciation cycles 1 . Linear response to Milankovitch forcing. Paleoceanography 7, 701-738.

Imbrie, J., Berger, A., Boyle, E.A., Clemens, S.C., Duffy, A., Howard, W.R., Kukla, G., Kutzbach, J., Martinson, D.G., McIntyre, A., Mix, A.C., Molfino, B., Morley, J.J., Peterson, L.C., Pisias, N.G., Prell, W.L., Raymo, M.E., Shackleton, N.J., Toggweiler, J.R., 1993. On the structure and origin of major glaciation cycles.2. The 100,000-year cycle. Paleoceanography 8, 699-735.

Jouzel, J., Masson-Delmotte, V., Cattani, O., Dreyfus, G., Falourd, S., Hoffmann, G., Minster, B., Nouet, J., Barnola, J.M., Chappellaz, J., Fischer, H., Gallet, J.C., Johnsen, S. Leuenberger, M., Loulergue, L., Luethi, D., Oerter, H., Parrenin, F., Raisbeck, G., Raynaud, D., Schilt, A., Schwander, J., Selmo, E., Souchez, R., Spahni, R., Stauffer, B., Steffensen, J.P. Stenni, B., Stocker, T.F., Tison, J.L., Werner, M., Wolff, E.W., 2007. Orbital and millennial Antarctic climate variability over the past 800,000 years. Science 317, 793-796.

Knorr, G., Lohmann, G., 2003. Southern Ocean origin for the resumption of Atlantic thermohaline circulation during deglaciation. Nature 424, 532-536.

Knorr, G., Lohmann, G., 2007. Rapid transitions in the Atlantic thermohaline circulation triggered by global warming and meltwater during the last deglaciation. Geochemistry, Geophysics, Geosystems 8, Q12006. doi:10.1029/2007GC001604.

Lambert, F., Delmonte, B., Petit, J.R., Bigler, M., Kaufmann, P.R., Hutterli, M.A., Stocker T.F., Ruth, U., Steffensen, J.P., Maggi, V., 2008. Dust-climate couplings over the past 800,000 years from the EPICA Dome C ice core. Nature 452, 616-619.

Lisiecki, L.E., Raymo, M.E., 2005. A Pliocene-Pleistocene stack of 57 globally distributed bentic $\delta^{18} \mathrm{O}$ records. Paleoceanography 20, PA1003. doi:10.1029/2004PA001071.

Markovic, S.B., Oches, E.A., McCoy, W.D., Frechen, M., Gaudenyi, T., 2007. Malacological and sedimentological evidence for "warm" glacial climate from the Irig loess sequence, Vojvodina, Serbia. Geochemistry Geophysics Geosystems 8.

Micolajewicz, U., 1998. Effect of meltwater input from the Antartic ice sheet on the thermohaline circulation. Annals of Glaciology 27, 311-320.

Mudelsee, M., Stattegger, K., 1997. Exploring the structure of the mid-Pleistocene revolution with advanced methods of time series analysis. Geologische Rundschau 86, 499-511.

Ninnemann, U.S., Charles, C.D., 1997. Regional differences in quaternary subantartic nutreint cycling: link to intermediate and deep water ventilation. Paleoceanography $12,560-567$.

Ninnemann, U.S., Charles, C.D., 2002. Changes in the mode of Southern Ocean circulation over the last glacial cycle revealed by foraminiferal stable isotopic variability. Earth and Planetary Science Letters 201, 383-396.

Oppo, D.W., Horowitz, M., 2000. Glacial deep water geometry: South Atlantic benthic foraminiferal Cd/Ca and delta C-13 evidence. Paleoceanography 15, 147-160.

Oppo, D.W., Lehman, S.J., 1993. Mid-depth circulation of the subpolar North-Atlantic during the Last Glacial Maximum. Science 259, 1148-1152.

Paillard, D., Parrenin, F., 2004. The Antarctic ice sheet and the triggering of deglaciations. Earth and Planetary Science Letters 227, 263-271.

Parrenin, F., R'emy, F., Ritz, C., Siegert, M.J., Jouzel, J., 2004. New modeling of the Vostok ice flow line and implication for the glaciological chronologt of the Vostok ice core. Journal of Geophysical Research 109, D20102. doi:10.1029/2004JD004561.

Parrenin, F., Barnola, J.M., Beer, J., Blunier, T., Castellano, E., Chappellaz, J., Dreyfus, G. Fischer, H., Fujita, S., Jouzel, J., Kawamura, K., Lemieux-Dudon, B., Loulergue, L. Masson-Delmotte, V., Narcisi, B., Petit, J.R., Raisbeck, G., Raynaud, D., Ruth, U., Schwander, J., Severi, M., Spahni, R., Steffensen, J.P., Svensson, A., Udisti, R., Waelbroeck, C., Wolff, E., 2007. The EDC3 chronology for the EPICA dome C ice core. Climate of the Past 3, 485-497.

Petit, J.R., Jouzel, J., Raynaud, D., Barkov, N.I., Barnola, J.M., Basile, I., Bender, M., Chappellaz, J., Davis, M., Delaygue, G., Delmotte, M., Kotlyakov, V.M., Legrand, M., Lipenkov, V.Y., Lorius, C., Pepin, L., Ritz, C., Saltzman, E., Stievenard, M., 1999. Climate and atmospheric history of the past 420,000 years from the Vostok ice core, Antarctica. Nature 399, 429-436.

Raymo, M.E., 1997. The timing of major climate terminations. Paleoceanography 12 , $577-585$.

Raymo, M.E., Oppo, D., Curry, W., 1997. The mid-Pleistocene climate transition: a deep sea carbon isotopic prespective. Paleoceanography 12, 546-559.

Raymo, M.E., Oppo, D.W., Flower, B.P., Hodell, D.A., McManus, J.F., Venz, K.A., Kleiven, K.F., McIntyre, K., 2004. Stability of North Atlantic water masses in face of pronounced climate variability during the Pleistocene. Paleoceanography 19 , PA2008. doi:10.1029/2003PA000921.

Robinson, R.S., Sigman, D.M., 2008. Nitrogen isotopic evidence for a poleward decrease in surface nitrate within the ice age Antarctic. Quaternary Science Reviews 27, 1076-1090.

Robinson, R.S., Brunelle, B.G., Sigman, D.M., 2004. Revisiting nutrient utilization in the glacial Antarctic: evidence from a new method for diatom-bound $\mathrm{N}$ isotopic analysis. Paleoceanography 19, PA3001. doi:10.1029/2003PA000996. 
Rothlisberger, R., Mudelsee, M., Bigler, M., de Angelis, M., Fischer, H., Hansson, M., Lambert, F., Masson-Delmotte, V., Sime, L., Udisti, R., Wolff, E.W., 2008. The Southern Hemisphere at glacial terminations: insights from the Dome C ice core. Climate of the Past 4, 345-356.

Ruddiman, W.F., Raymo, M.E., Martinson, D., Clement, A.C., Backman, J., 1989. Pliestocene evolution: Northern Hemisphere ice sheet and North Atlantic Ocean. Paleoceanography 4, 353-412.

Rutberg, R.L., Hemming, S.R., Goldstein, S.L., 2000. Reduced North Atlantic Deep Water flux to the glacial Southern Ocean inferred from neodymium isotope ratios. Nature 405, 935-938.

Sarmiento, J.L., Toggweiler, J.R., 1984. A new model for the role of the oceans in detrmining atmospheric $\mathrm{pCO}_{2}$. Nature $308,621-624$

Sarmiento, J.L., Gruber, N., Brzezinski, M.A., Dunne, J.P., 2004. High-latitude controls of thermocline nutrients and low latitude biological productivity. Nature 427, 56-60.

Schneider-Mor, A., Yam, R., Bianchi, C., Kunz-Pirrung, M., Gersonde, R., Shemesh, A 2005. Diatom stable isotopes, sea ice presence and sea surface temperature records of the past $640 \mathrm{ka}$ in the Atlantic sector of the Southern Ocean. Geophysical Research Letters 32, L10704. doi:10.1029/2005GL022543.

Schneider-Mor, A., Yam, R., Bianchi, C., Kunz-Pirrung, M., Gersonde, R., Shemesh, A., 2008. The nutrient regime at the siliceous belt of the Atlantic sector of the Southern Ocean during the past 660 kyr. Paleoceanography PA3217. doi:10.1029/ 2007PA001466.

Shackleton, N.J., 1987. Oxygen isotopes, ice volume and sea level. Quaternary Science Reviews 6, 183-190.

Shemesh, A., Hodell, D.A., Kanfoush, S.L., Charles, C.D., Guilderson, T.P., 2002. The sequence of events during the last deglaciation in Southern Ocean sediments and Antarctic ice cores. Paleoceanography 17, 1056. doi:10.1029/2000PA000599.

Shin, S.I., Liu, Z.G., Otto-Bliesner, B.L., Kutzbach, J.E., Vavrus, S.J., 2003. Southern Ocean sea-ice control of the glacial North Atlantic thermohaline circulation. Geophysica Research Letters 30, 1096. doi:10.1029/2002GL015513.

Sigman, D.M., Boyle, E.A., 2000. Glacial/interglacial variations in atmospheric carbon dioxide. Nature $407,859-869$.
Sigman, D.M., Altabet, M.A., Francois, R., McCorkle, D.C., Gaillard, J.F., 1999. The isotopic composition of diatom-bound nitrogen in Southern Ocean sediments. Paleoceanography $14,118-134$.

Singer, A.J., Shemesh, A., 1995. Climatically linked carbon isotope variation during the past 430,000 years in Southern Ocean sediments. Paleoceanography 10,171-177.

Stephens, B.B., Keeling, R.F., 2000. The influence of Antarctic sea ice on glacial-interglacial $\mathrm{CO}_{2}$ variations. Nature 404, 171-174.

Sun, Y. Chen, J. Clemens, S.C. Liu, Q S. Ji, JF. Tada, R, 2006. East Asian monsoon variability over the last seven glacial cycles recorded by a loess sequence from the northwestern Chinese Loess Plateau. Geochemistry, Geophysics, Geosystems 7, Q12002. doi:10.1029/2006GC001287.

Toggweiler, J.R., 1999. Variation of atmospheric $\mathrm{CO}_{2}$ by ventilation of the ocean's deepest water. Paleoceanography 14, 571-588.

Toggweiler, J.R., 2008. Origin of the 100,000-year timescale in Antarctic temperatures and atmospheric CO2. Paleoceanography 23, PA2211. doi:10.1029/2006PA001405.

Vaks, A., Bar-Matthews, M., Ayalon, A., Matthews, A., Frumkin, A., Dayan, U., Halicz, L., Almogi-Labin, A., Schilman, B., 2006. Paleoclimate and location of the border between Mediterranean climate region and the Saharo-Arabian Desert as revealed by speleothems from the northern Negev Desert, Israel. Earth and Planetary Science Letters 249, 384-399.

Wang, Y.J., Cheng, H., Edwards, R.L., Kong, X.G., Shao, X.H., Chen, S.T., Wu, J.Y., Jiang, X.Y., Wang, X.F., An, Z.S., 2008. Millennial- and orbital-scale changes in the East Asian monsoon over the past 224,000 years. Nature 451, 1090-1093.

Winckler, G., Anderson, R.F., Schlosser, P., 2005. Equatorial Pacific productivity and dust flux during the mid-Pleistocene climate transition. Paleoceanography 20, PA4025. doi:10.1029/2005PA001177.

Wolff, E.W., Fischer, H., Fundel, F., Ruth, U., Twarloh, B., Littot, G.C., Mulvaney, R., Rothlisberger, R., de Angelis, M., Boutron, C.F., Hansson, M., Jonsell, U., Hutterli, M.A., Lambert, F., Kaufmann, P., Stauffer, B., Stocker, T.F., Steffensen, J.P., Bigler, M., Siggaard-Andersen, M.L., Udisti, R., Becagli, S., Castellano, E., Severi, M., Wagenbach, D., Barbante, C., Gabrielli, P., Gaspari, V., 2006. Southern Ocean sea-ice extent, productivity and iron flux over the past eight glacial cycles. Nature 440, 491-496. 